\title{
Small islands, strategic locales and the configuration of first Lapita settlement of Vanua Levu, northern Fiji
}

\author{
David V. Burley, Travis Freeland and Jone Balenaivalu
}

\begin{abstract}
The Cakaulevu barrier reef provides a substantial impediment for maritime access to the northern shores of Vanua Levu, the second largest island in Fiji. Archaeological survey on the northeastern segment of this coast has documented colonising sites with Western Lapita ceramics on the offshore islands of Vorovoro and Kavewa. Both islands are small and, for Lapita settlement, strategically positioned on passages through the reef. Investigations at Vorovoro are previously published; those for Kavewa are presented here. Ceramic data suggest a relationship between the two Lapita sites and they are interpreted as a founder group for north-eastern Vanua Levu. The implication of this claim for the broader context of Vanua Levu settlement is examined in preliminary discussion.
\end{abstract}

\section{Introduction}

Archaeological discovery of Lapita colonising sites in Remote Oceania has repeatedly illustrated a settlement strategy where earlier or founder settlements are positioned on small offshore islands. Nunn and Heorake provide a substantive review illustrating that, even where sites are located on larger islands, they often occur in coastal fringe contexts that are 'transitional between ocean and land' (2009:250-251). What they mean here is that palaeogeographic and palaeoenvironmental reconstructions of several of these locales either identify them as small near-shore islets separated by a narrow channel from the mainland, or they occur on sand spits or tombolo features where stilt house construction would be required. To understand and explain the logic behind this pattern, they suggest it was largely pragmatic, one likely driven by a reef-centred subsistence economy as well as a generally healthier situation where disease-carrying insects are less common on small islands. In a related paper, Nunn and Carson (2015:17) take this one step beyond, suggesting that decreasing sea levels by $2750 \mathrm{cal}$. BP eliminated or heavily impacted any advantage these small island environments might have had for subsistence, forcing a reconfiguration of economy to agricultural production on larger islands. This transition, in their view, marks the end or near-end for Lapita in many regions across Oceania. 
One cannot dispute the dominance of small island occupation sites for Lapita founder settlements across Oceania. One also cannot argue against their location in well-suited environments for a reef-centred subsistence regime. But whether the latter necessarily is the exclusive driver for decisions over initial occupation locales might be questioned. For example, critical passage for sailing canoes, concerns of defence from unknown populations or fauna, strategic planning for continued exploration, and settlement locales in sites easily located by incoming canoes seem equally compelling factors. These factors were underscored in 2012 when Burley (2012) attempted to explain an Early Lapita site on Vorovoro Island off the northern coast of Vanua Levu in Fiji. Occurring on a very small island with limited resources in support of settlement, it could be understood only as a gateway community at the head of Mali Passage on the inner side of Cakaulevu, the Great Sea Barrier Reef. In this paper, we report on a virtually identical Lapita site location on Kavewa Island, again strategically situated in a small island context with critical passage through the Cakaulevu Barrier Reef. Unlike Vorovoro, however, Kavewa Island incorporates both logistics and a resource-rich environment, as argued for by Nunn and Heorake (2009). The Kavewa and Vorovoro Lapita sites facilitate a preliminary discussion of Lapita colonisation and occupation of Vanua Levu.

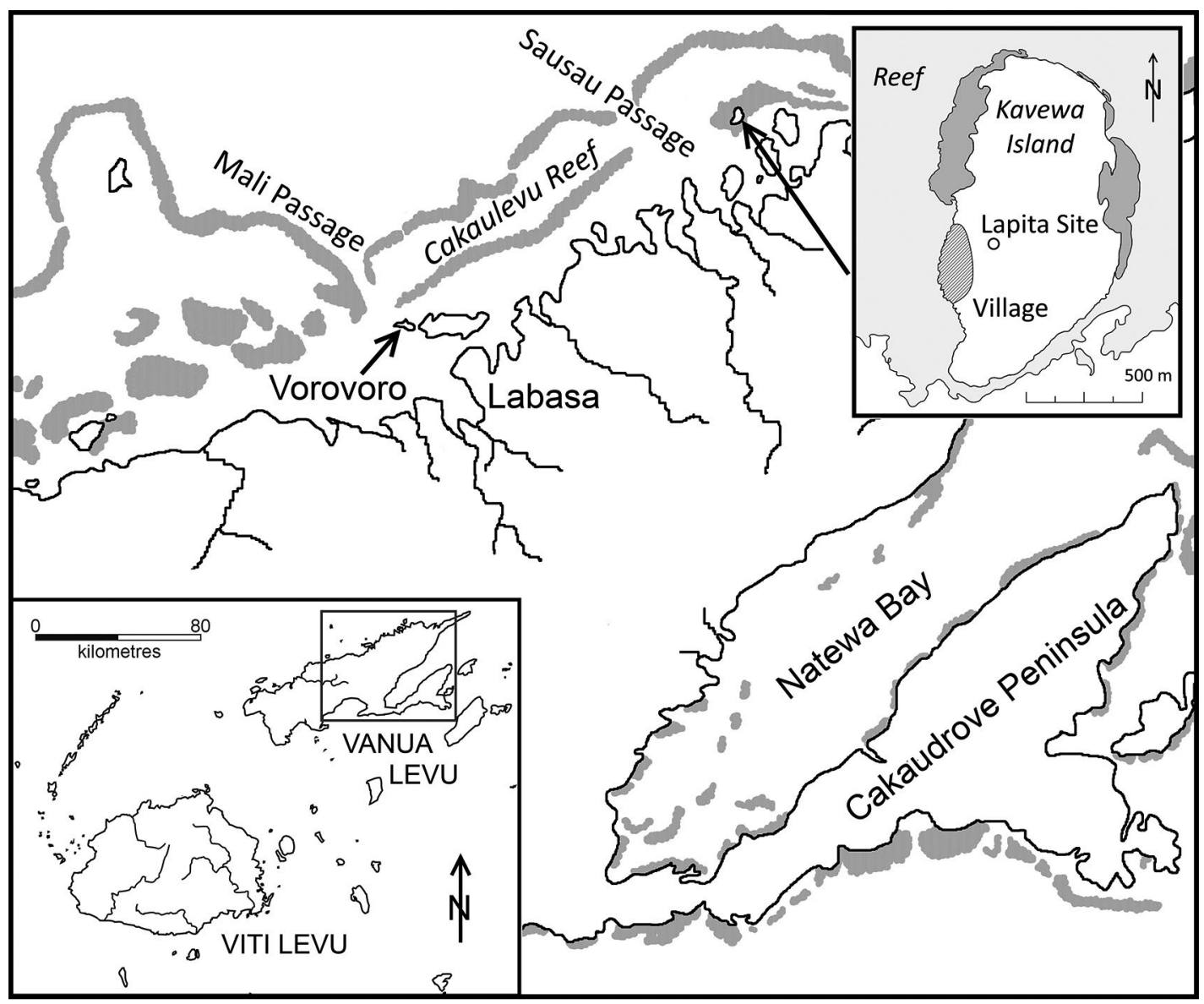

Figure 8.1. Vanua Levu and Cakaulevu Barrier Reef with Vorovoro and Kavewa sites identified.

Source: Illustration by Vienna Chichi Lam. 


\section{Vanua Levu, Vorovoro and discovery of the Kavewa Lapita site}

Vanua Levu is the second largest island in the Fiji group $\left(5587 \mathrm{~km}^{2}\right.$ in area) with an interior mountainous core and an orographic rainfall pattern where the leeward north coast receives far less precipitation than the southern windward one. Despite its size, and the substantial number of archaeological projects undertaken elsewhere in Fiji since pioneering work in the 1940s (Gifford 1951), there was limited archaeological investigation on Vanua Levu prior to 2009 (Parke 1971, 1972, 2000). In 2009, Burley (2010) began an initial survey of select areas on the south Cakaudrove Peninsula as well as coastal areas adjacent to Labasa on the island's north-eastern shore (Figure 8.1). On the final day of that latter survey, a Lapita site with dentate ceramics was unexpectedly found in a back-beach garden on the small island of Vorovoro opposite the mouth of the Labasa River.

The Vorovoro discovery was unexpected, for the island is small $\left(0.75 \mathrm{~km}^{2}\right)$, it has no freshwater source, there is limited agricultural soil and the leeward reef is restricted for foreshore exploitation. Further investigations were undertaken at Vorovoro in 2010 with test excavations, surface collection and site mapping projects. Vorovoro Lapita ceramic motifs are complexly applied and of Western Lapita design (Burley 2012:6-7). Combined with radiocarbon dates suggesting an age of 3050-3000 cal. BP (Burley 2012:9), as well as the presence of Kutau-Bao obsidian (Ross-Sheppard et al. 2013), Vorovoro has been interpreted as a founder colony. Without ecological advantage for settlement in the sense of Nunn and Heorake (2009), its location had to be strategic, a settlement easily accessed via Mali Passage and one central to further exploration during Early Lapita colonisation (Burley 2012:10-11).

Additional survey for Lapita and mid-sequence archaeological sites on the northern Vanua Levu coastline and offshore islands was carried out between 2010 and 2012. Of particular interest for archaeological survey was Kavewa Island, $33 \mathrm{~km}$ north-east of Vorovoro. Like Vorovoro, Kavewa is a small islet positioned at the head of Sausau Passage, another of the major breaks in the Cakaulevu barrier reef (Figure 8.1). Unlike Vorovoro, however, Kavewa is surrounded by a productive fringing reef, has rich agricultural soils, a number of freshwater springs and supports a sizeable contemporary village. Western-style Lapita sherds almost identical to those from Vorovoro were recovered on Kavewa in 2011. A small project in 2012 carried out additional surface collection and limited test excavations to document site extent and characteristics.

\section{Kavewa Island and the Kavewa Lapita site}

Kavewa Island is $8 \mathrm{~km}$ east of the inner side of Sausau Passage, this being a 1.4-km-wide deep channel through the Cakaulevu reef. The island is also $6 \mathrm{~km}$ straight line distance north of the Vanua Levu coast where dense mangrove fringe dominates the shoreline today. In island size, Kavewa is slightly larger than Vorovoro, being c. $1.4 \mathrm{~km}$ north-south by $0.75 \mathrm{~km}$ eastwest (Figure 8.1). The island is underlain by strata of Malau breccias (Rickard 1966), deposited during the late Miocene from the Udu volcanic axis of Vanua Levu. Two summits dominate island geography, one rising to $62 \mathrm{~m}$ on the north, the other being up to $43 \mathrm{~m}$ on the south. Intervening, and serving as a central ridge, is a lower saddle rising to $14 \mathrm{~m}$. The present village is located on the south-west coast, on an elevated sand flat with frontal beach and fringing reef. The village is one of four settlements under allegiance to the Turaga na Tui Nadogo, paramount chief of Nadogo subdistrict. Local villagers had limited knowledge of traditional history for this village, a situation also in contrast to Vorovoro (Burley 2012:11). 
Palaeo-shorelines at the time of first Lapita settlement for northern Vanua Levu are inferred to be c. $1 \mathrm{~m}$ higher than present (Nunn and Peltier 2001). The Kavewa Lapita site occurs on a sandy beach ridge now positioned $160 \mathrm{~m}$ inland of the present village and $250 \mathrm{~m}$ due east of the current shore. When occupied, the site would have been at the head of a broadly formed embayment. Subsequently, this was in-filled with calcareous sand, presumably as sea levels fell. The northern Vanua Levu coast and offshore islands have been subject to differential tectonic uplift in the Holocene (Ellison and Fiu 2010; Nunn and Peltier 2001). This, too, may help to account for the now inland locale of the Lapita occupation. Substantial scatters of late prehistoric and mid-sequence ceramics occur in surface deposits at the back of the village, and in gardens intervening between the village and the Lapita site. This indicates a seaward-moving settlement as sand accumulation and/or emergence took place.

Two freshwater springs and wetlands or ponds occur near the Kavewa Lapita site, while an intermittent streambed created by seasonal runoff dissects the modern village landscape. Importantly, the inland side of the sand ridge on which the Lapita site occurs drops 0.75 to $1.0 \mathrm{~m}$ into one of these wetland depressions (Figure 8.2). This basin, approximately 35 by $35 \mathrm{~m}$ in size, is defined on its opposite side by the steeply rising slope of the inland saddle. Abundant shell, ceramics and other materials mixed in surface deposits along the edge of the wetland associate it with first settlement by Lapita people as well as later occupations. A late prehistoric yavu (house platform) occurs here as well. This area locally is referred to as Waidroka, literally translated as fresh (droka) water (wai). It would have been a central feature for initial settlement during the Lapita phase, as well as subsequent occupations.

\section{Investigations at Kavewa 2012}

A small assemblage of decorated Lapita ceramics was recovered from the Kavewa site surface during a brief visit in 2011. The presence of expanded zone markers, in-filled triangles, densely impressed dentate stamp and other features indicated an earlier Lapita occupation, one with affinities to the Western Lapita stylistic aspect as well as the nearby Vorovoro site. The distribution of these sherds suggested a limited spatial extent for the occupation and an expedient shovel test indicated a c. $40 \mathrm{~cm}$ shell midden stratum overlying sand, within which ceramics continued to be found. The 2012 project was intended to provide a more definitive assessment of the Lapita occupation through site clearance, additional survey and limited test excavations during a five-day period. Initial surface clearance and survey reconfirmed the previous distribution of Lapita ceramics as a concentrated area on the edge of the basin/wetland feature. A north-south baseline was established parallel to the western edge of the basin and two 1 by $1 \mathrm{~m}$ excavation units (Units 1 and 3) were positioned along its axis (Figure 8.2). The excavations were dug by trowel in $10 \mathrm{~cm}$ arbitrary spits in the upper levels with $20 \mathrm{~cm}$ spits employed in the lower ones. All removed matrices were passed through nested sieves of $6.4 \mathrm{~mm}$ and $3.2 \mathrm{~mm}$ mesh.

The excavation units reveal a consistent stratigraphy of four definable strata (Figure 8.2). Stratum I, up to c. $50 \mathrm{~cm}$ in depth below surface (dbs), incorporates Stratum Ia, an upper dark brown loam/clay with compact blocky structure that transitions into Ib, a less dense loam/mixedshell midden of looser composition. Ceramics and other artefacts in Stratum I are abundant but chronologically mixed, including dentate-stamped Lapita sherds occurring with later types of Fijian pottery. Postholes and pit features were encountered in both excavation units, either within Stratum I or extending from Stratum I into Stratum II. Stratum II is highly distinctive and sharply separated from Stratum I. This stratum consists of reddish-brown sand varying in thickness between $65 \mathrm{~cm}$ (Unit 1) and $40 \mathrm{~cm}$ (Unit 3); shell, ceramics and non-ceramic artefacts occur throughout. Earlier Lapita deposits occur in the bottom 15 to $20 \mathrm{~cm}$ of this 
stratum (c. $70 \mathrm{~cm}$ dbs) seemingly with a degree of integrity. Associated charcoal samples for radiocarbon dating, unfortunately, were not recovered. Stratum III is an underlying yellow coral sand of variable thickness below which is Stratum IV, white coral sand. Occasional but limited archaeological materials were recovered in Stratum III, presumably transposed from Stratum II. Stratum IV was identified in both excavation units at $120-125 \mathrm{~cm}$ below surface by an auger test in the bottom of each excavation unit.
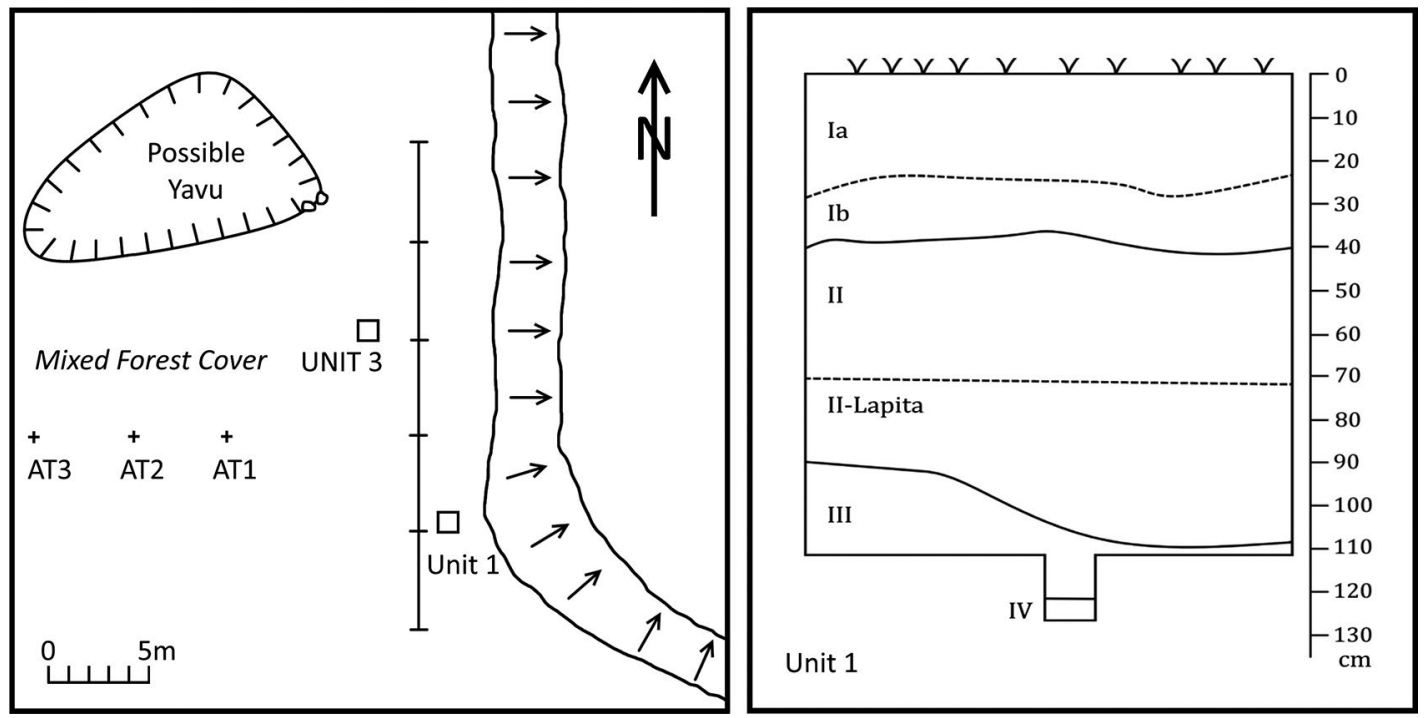

Figure 8.2. Kavewa Lapita site location, excavation plan and Unit 1 stratigraphic profile.

Stratum descriptions are provided in text.

Source: Illustration by Vienna Chichi Lam.

Beginning $10 \mathrm{~m}$ west of the baseline, a set of three auger tests was dug at $5 \mathrm{~m}$ intervals to identify the depth of stratigraphic breaks and thickness of deposits as the Kavewa site extends toward the current shore. Site stratigraphy continues to be consistent, with Stratum I of identical thickness, but in Stratum II the red sand progressively thins out to $20 \mathrm{~cm}$ in thickness. This requires further verification but the in situ Lapita occupation is taken to extend westward a maximum of $25 \mathrm{~m}$ from the basin-wetland feature edge. Surface distribution of decorated ceramics also suggests a $30 \mathrm{~m}$ north-south extent corresponding with the established baseline. The Kavewa Lapita site in this respect was no more than a hamlet $\left(750 \mathrm{~m}^{2}\right.$ area $)$, presumably having a limited population.

\section{The Kavewa assemblage}

The artefact assemblage recovered from archaeological test excavations at Kavewa is relatively abundant but dominantly Post-Lapita in age. In Table 8.1, a total of 4404 ceramic fragments are tabulated for Units 1 and 3 by individual spits in each of the excavation units. Only 6.1 per cent of these were recovered in the basal two spits of each unit, where proveniences are assigned to the Lapita period with a relative degree of confidence. Decorated sherds identified in the table largely incorporate dentate-stamping, incision and notching on lip or shoulder with limited others having appliqué modelling, side tool impression, slip application or some other treatment. The large majority of decorated sherds are Lapita or Late Lapita in age. The presence of these sherds in the upper midden Stratum I deposit is a consequence of site disturbances over the past two and a half millennia. Stratum II, the reddish sand, similarly has disturbance in the upper spits, but there appears to be a greater degree of consistency and coherence. For example, the relative number of decorated sherds to overall ceramic counts by spit in the assemblage increases 
sharply with depth in Stratum II. In the bottom two spits for Units 1 and 3, decorated sherds respectively represent 10.5 per cent and 14.6 per cent of the total; all decorated sherds in these levels are diagnostic of Lapita.

Table 8.1. Ceramic distribution by Unit, Spit and Stratum for excavated units at Kavewa.

\begin{tabular}{|c|c|c|c|c|c|c|c|}
\hline \multicolumn{2}{|c|}{ Provenience } & \multirow{2}{*}{$\begin{array}{ll}\text { DRS } \\
4\end{array}$} & \multirow{2}{*}{$\begin{array}{ll}\text { DBS } \\
-\end{array}$} & \multirow{2}{*}{$\begin{array}{l}\text { PRS } \\
22\end{array}$} & \multirow{2}{*}{$\begin{array}{l}\text { PBS } \\
220 \\
\end{array}$} & \multirow{2}{*}{$\begin{array}{l}\text { 0ther } \\
1\end{array}$} & \multirow{2}{*}{$\begin{array}{r}\text { Total } \\
247 \\
\end{array}$} \\
\hline Unit 1 & Surface & & & & & & \\
\hline Unit 1 & 1 (Strat la) & 1 & 4 & 24 & 419 & - & 448 \\
\hline Unit 1 & 2 (Strat la) & - & 2 & 19 & 494 & 1 & 516 \\
\hline Unit 1 & 3 (Strat Ib) & 5 & 2 & 6 & 222 & & 235 \\
\hline Unit 1 & 4 (Strat Ib) & 4 & 4 & 2 & 118 & 1 & 129 \\
\hline Unit 1 & 5 (Strat II) & 2 & 2 & 3 & 146 & - & 153 \\
\hline Unit 1 & 6 (Strat II) & - & 7 & 1 & ??? & - & 8 \\
\hline Unit 1 & 7 (Strat II) & 3 & 2 & 3 & 50 & 1 & 59 \\
\hline Unit 1 & 8 (Strat II-L) & 2 & 5 & 1 & 58 & 3 & 69 \\
\hline Unit 1 & 9 (Strat II-L) & 2 & 9 & 3 & 43 & 1 & 58 \\
\hline Unit 3 & Surface & 1 & 2 & 4 & 158 & 1 & 166 \\
\hline Unit 3 & 1 (Strat la) & 3 & 8 & 26 & 719 & 1 & 757 \\
\hline Unit 3 & 2 (Strat Ib) & 1 & 4 & 8 & 388 & - & 401 \\
\hline Unit 3 & 3 (Strat Ib) & 4 & 2 & 8 & 309 & - & 323 \\
\hline Unit 3 & 4 (Strat Ib) & 2 & 1 & 6 & 208 & - & 217 \\
\hline Unit 3 & 5 (Strat Ib) & 4 & 6 & 5 & 121 & 1 & 137 \\
\hline Unit 3 & 6 (Strat II) & 1 & 1 & 7 & 113 & - & 122 \\
\hline Unit 3 & 7 (Strat II-L) & 1 & 10 & 1 & 39 & - & 51 \\
\hline Unit 3 & 8 (Strat II-L) & - & 4 & 1 & 87 & 1 & 93 \\
\hline Unit 3 & Feature & - & 3 & 4 & 208 & - & 215 \\
\hline Total & & 40 & 78 & 154 & 4120 & 12 & 4404 \\
\hline
\end{tabular}

DRS=decorated rim sherd, DBS=decorated body sherd, PRS=plain rim sherd, PBS=plain body sherd, 'Other' refers to handles, spout and other oddities. For Unit 1, Spit 6, the plain body sherds were misplaced in the field laboratory and a total count was not recorded.

Source: Authors' data.

Lapita ceramic motifs and their application at Kavewa are similar to those documented for the Vorovoro site but also other earlier Lapita settlements in Fiji (Figures 8.3 and 8.4). Most notable in this respect is the complexity of motif design and application, the latter employing highly dense dentate impressions (see LeBlanc 2016). Also important is the presence of restricted zone markers with overlapping or tightly spaced dentate lines; a few of these seem to define a central frieze with one (Figure 8.4f) possibly incorporating a bottom loop for a face motif and another (Figure 8.3f) appearing to be a fragment of a double face motif with an ear spool design (for the latter, Matthew Spriggs pers. comm. 2019).

In-filled triangles, a variant of the labyrinth motif and a large flat-bottom dish are other comparable features. As at Vorovoro, and other early sites in central/western Fiji, decorative applications seem more characteristic of the Western Lapita stylistic province than the simplified and open geometric and curvilinear patterns of Eastern Lapita in Tonga and Lau (Burley and LeBlanc 2015). 


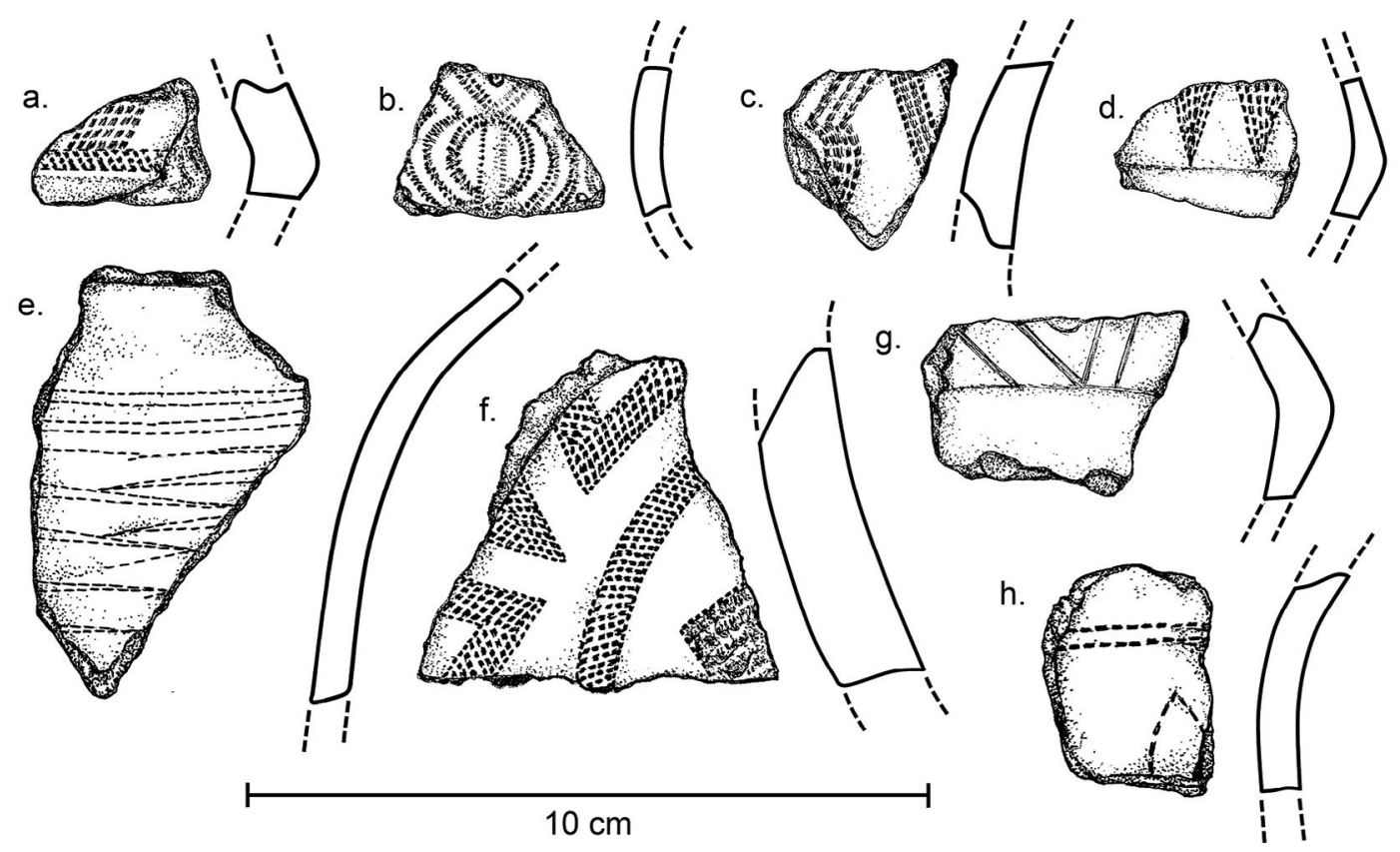

Figure 8.3. Kavewa decorated Lapita ceramics:(A-F, H) dentate-stamped; $(G)$ incised. (A, F) expanded zone marker; $(B)$ fine and densely applied dentate; $(D)$ in-filled triangle; $(F)$ has indistinct stamp mark lower right.

Source: Illustration by Vienna Chichi Lam.

a.

c.
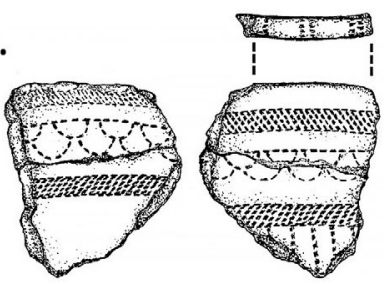

b.
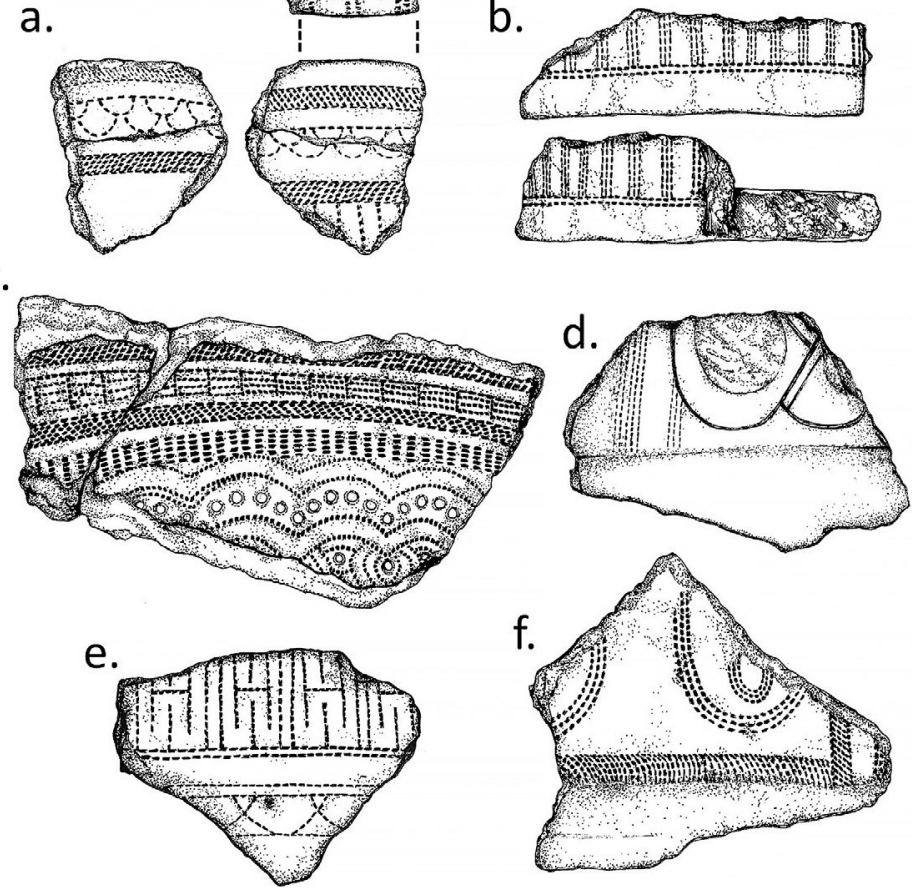

Figure 8.4. Kavewa decorated Lapita ceramics, all dentate-stamped: (A) decorated inside and out plus on lip; (B) two views of flat-bottom tray or bowl; (C) densely applied dentate motifs; (D) incised outline for indistinct stamp; (E) variation of labyrinth motif; (F) possible nose loops for face motif with expanded zone marker.

Source: Illustration by Vienna Chichi Lam. 
Dickinson (2015) conducted petrographic analysis on seven Kavewa ceramic sherds from Unit 1, Stratum II-L, Spit 8; five were decorated Lapita body sherds. His analysis identified four 'generically contrasting types of temper sands', two of these being quartzose-rich and directly attributed to Kavewa Island or the Udu volcanic group with which it is affiliated. The remaining two, however, are quartz-free felspathic tempers with $(\mathrm{n}=3)$ and without $(\mathrm{n}=1)$ calcareous sand mix. Quartz-free felspathic tempers affiliate with the Natewa volcanic group, a geological formation somewhat south of Kavewa. Vorovoro Island also has formed as part of the Udu volcanic group but lies on its border with the Natewa group. The Vorovoro Lapita ceramic assemblage has ceramic tempers from both Udu and Natewa (Burley 2012:8) and it seems probable that the Kavewa-Natewa tempers represent ceramic transfer and intercommunity contact.

Almost all of the non-ceramic archaeological assemblage is Post-Lapita in age (Table 8.2). Lithic drills/preforms, lithic flakes and shell bead preforms are most abundant. These seemingly are complementary, with stone drills/preforms being part of a bead maker's tool kit. The lithic assemblage is predominantly quartz and chalcedony with opaque coloured cherts also present. Lithic materials recovered from the Lapita associated spits are exclusively quartz flakes or shatter. All of the lithic material types can be acquired locally.

Table 8.2. Non-ceramic artefact distribution by Unit, Spit and Stratum for excavated units at Kavewa.

\begin{tabular}{|c|c|c|c|c|c|c|c|c|c|c|c|}
\hline \multicolumn{2}{|c|}{ Provenience } & \multirow[t]{2}{*}{ Drill } & \multirow{2}{*}{$\begin{array}{c}\text { Lithic } \\
\text { Debitage }\end{array}$} & \multirow{2}{*}{$\begin{array}{l}\text { Other } \\
\text { Lithic }\end{array}$} & \multirow{2}{*}{$\begin{array}{l}\text { Disc } \\
\text { Bead }\end{array}$} & \multirow{2}{*}{$\begin{array}{l}\text { Drilled } \\
\text { Preform }\end{array}$} & \multirow[t]{2}{*}{ Disc } & \multirow[t]{2}{*}{ Bracelet } & \multirow{2}{*}{$\begin{array}{l}\text { Other } \\
\text { Shell }\end{array}$} & \multirow{2}{*}{$\begin{array}{c}\text { Coral } \\
\text { Abrader }\end{array}$} & \multirow[t]{2}{*}{ Total } \\
\hline Unit & Spit (Stratum) & & & & & & & & & & \\
\hline 1 & 1 (Strat la) & 6 & 255 & - & - & 1 & - & 1 & - & 2 & 265 \\
\hline 1 & 2 (Strat la) & 3 & 115 & - & - & - & - & - & 3 & - & 121 \\
\hline 1 & 3 (Strat Ib) & 1 & 48 & - & - & - & 1 & - & - & - & 50 \\
\hline 1 & 4 (Strat Ib) & - & 29 & - & - & - & - & - & - & - & 29 \\
\hline 1 & 5 (Strat II) & - & 10 & - & - & - & - & 1 & 1 & - & 12 \\
\hline 1 & 6 (Strat II) & - & 8 & - & - & - & - & - & - & 1 & 9 \\
\hline 1 & 7 (Strat II) & - & 8 & - & - & - & - & - & - & - & 8 \\
\hline 1 & 8 (Strat II-L) & - & 8 & - & - & - & - & 1 & - & 1 & 10 \\
\hline 1 & 9 (Strat II-L) & - & - & - & - & - & - & - & - & - & - \\
\hline 3 & 1 (Strat la) & 70 & 813 & - & 7 & 7 & 11 & - & - & 1 & 909 \\
\hline 3 & 2 (Strat Ib) & 10 & 241 & 1 & 2 & 3 & 27 & - & - & - & 284 \\
\hline 3 & 3 (Strat Ib) & 8 & 169 & - & 2 & 3 & 31 & - & - & 2 & 215 \\
\hline 3 & 4 (Strat Ib) & 1 & 19 & - & - & 1 & 1 & - & - & - & 22 \\
\hline 3 & 5 (Strat Ib) & - & 7 & 1 & 1 & 1 & 1 & - & - & - & 11 \\
\hline 3 & 6 (Strat II) & 1 & 3 & - & 1 & - & 9 & - & - & - & 14 \\
\hline 3 & 7 (Strat II-L) & - & 2 & - & - & - & - & - & - & - & 2 \\
\hline 3 & 8 (Strat II-L) & - & 3 & - & - & - & - & - & - & - & 3 \\
\hline 3 & Feature & - & 13 & - & 4 & 2 & 17 & - & - & - & 36 \\
\hline Total & & 100 & 1751 & 2 & 17 & 18 & 98 & 3 & 4 & 7 & 2000 \\
\hline
\end{tabular}

The identifications of Drill/Preforms is provisional, while lithic flakes may also include expedient tools with use related edge retouch.

Source: Authors' data.

Finally, the faunal assemblage for Kavewa is small but potentially informative (Table 8.3). Fish is in the majority (61.3 per cent) but with a large number of turtle elements spread throughout Strata I and II (15.7 per cent). Kavewa, and the nearby offshore sand cay of Katawaqa, are documented nesting beaches today. That turtle is almost the total faunal assemblage for the assigned Lapita spits in Unit 3 indicates the Lapita settlers took advantage of this resource. Shellfish were not systematically collected in the test excavations. A diversity of species including Tridacna, 
Anadara, Gafrarium, Atactodea, Strombus, Lambis and Trochus are present both in surface scatter and in the excavated matrices. Lambis lambis and Trochus niloticus were particularly notable in Stratum II for their larger size.

Table 8.3. NISP faunal counts by Unit, Spit and Stratum for excavated units at Kavewa.

\begin{tabular}{|c|c|c|c|c|c|c|c|c|c|}
\hline \multicolumn{2}{|c|}{ Provenience } & \multirow{2}{*}{\begin{tabular}{r|} 
Fish \\
6
\end{tabular}} & \multirow{2}{*}{$\begin{array}{r}\text { Turtle } \\
-\end{array}$} & \multirow{2}{*}{$\frac{P i g}{3}$} & \multirow{2}{*}{ Bird } & \multirow{2}{*}{ Bat } & \multirow{2}{*}{ Rat } & \multirow{2}{*}{\begin{tabular}{r|} 
Unid. \\
3
\end{tabular}} & \multirow{2}{*}{$\begin{array}{r}\text { Total } \\
12 \\
\end{array}$} \\
\hline Unit 1 & Surface & & & & & & & & \\
\hline Unit 1 & 1 (Strat la) & 10 & 4 & - & - & - & - & 6 & 20 \\
\hline Unit 1 & 2 (Strat la) & 14 & & - & - & - & - & - & 14 \\
\hline Unit 1 & 3 (Strat Ib) & 9 & 4 & - & - & - & - & - & 13 \\
\hline Unit 1 & 4 (Strat Ib) & 21 & 3 & - & - & - & - & - & 24 \\
\hline Unit 1 & 5 (Strat II) & 22 & 4 & - & - & - & - & 7 & 33 \\
\hline Unit 1 & 6 (Strat II) & 45 & 5 & 1 & - & - & - & 12 & 63 \\
\hline Unit 1 & 7 (Strat II) & 34 & & 1 & 3 & - & - & 17 & 55 \\
\hline Unit 1 & 8 (Strat II-L) & 24 & 4 & - & - & 3 & - & 16 & 47 \\
\hline Unit 1 & 9 (Strat II-L) & 2 & - & - & - & - & - & 2 & 4 \\
\hline Unit 3 & Surface & 21 & - & - & - & - & - & - & 21 \\
\hline Unit 3 & 1 (Strat la) & 69 & 4 & - & - & - & - & 23 & 96 \\
\hline Unit 3 & 2 (Strat Ib) & 24 & & - & 2 & - & - & 10 & 36 \\
\hline Unit 3 & 3 (Strat Ib) & 30 & 8 & - & - & - & - & 15 & 53 \\
\hline Unit 3 & 4 (Strat Ib) & 10 & 7 & - & - & - & - & - & 17 \\
\hline Unit 3 & 5 (Strat Ib) & 4 & 4 & - & - & - & - & & 8 \\
\hline Unit 3 & 6 (Strat II) & 9 & 13 & - & - & - & - & 9 & 31 \\
\hline Unit 3 & 7 (Strat II-L) & 2 & 23 & - & 2 & - & - & - & 27 \\
\hline Unit 3 & 8 (Strat II-L) & 4 & 12 & - & - & - & - & - & 16 \\
\hline Unit 3 & Feature & 10 & & - & - & - & 3 & 4 & 17 \\
\hline Total & & 370 & 95 & 5 & 7 & 3 & 3 & 124 & 607 \\
\hline
\end{tabular}

Unid=unidentified.

Source: Authors' data.

\section{Preliminary discussion on the Lapita settlement of Vanua Levu}

Linguist Paul Geraghty (1983) has proposed that the dialects of eastern Vanua Levu were at some point in their distant past closely aligned to the languages of Lau and West Polynesia in contradistinction to areas within the Western Fiji group, including western Vanua Levu. The eastern Vanua Levu-Lau-Western Polynesian group is labelled Proto-Tokalau Fijian. In Geraghty's view, this is not only the ancestral language from which Proto-Polynesian emerged, but also that eastern Vanua Levu 'should not be discounted as a possible Polynesian homeland' (1983:382). Linguistic relationships thus provide a potentially intriguing role for eastern Vanua Levu in the larger picture of Oceanic settlement. The limited survey work in 2009 and subsequently was in order to provide an initial test of this hypothesis. The alternative, that eastern Vanua Levu was settled or resettled by Proto-Tokalau Fijian speakers from the east (Lau or Tonga) was considered a possibility as well.

For reasons explained in earlier discussion, the Vorovoro Lapita settlement is interpreted as a founder colony and gateway community facilitating exploration and settlement of the Vanua Levu mainland (Burley 2012:11). Its Western Lapita-style ceramic assemblage and associated radiocarbon dates are closely related to ceramic assemblages from the Bourewa and Naigani 
Lapita sites in central and western Fiji (Irwin et al. 2011; Nunn 2007), both considered possible founder colonies. Kavewa Lapita ceramics represent only a small sample from surface scatter and two 1 by $1 \mathrm{~m}$ excavation units. Yet their stylistic similarity to Vorovoro suggests some form of relationship; the presence of Natewa volcanic-derived temper sands in Kavewa pottery also suggests interaction between the communities. Kavewa and Vorovoro thus may be interpreted as a collective founder group for north-eastern Vanua Levu. This inference seems strengthened by their almost identical locales on the inner side of sequential passages through the Cakaulevu barrier reef (Figure 8.1). They appear as sentinels in a metaphoric if not literal sense, where incoming or departing Lapita canoes are guided to these sites.

In having a continuous occupation from Early Lapita landfall through to the present, Kavewa and Vorovoro islands are contrary to the Nunn and Carson (2015) arguments for small island abandonment at the end of the Lapita period. And while it is possible, if not probable, that shifts in subsistence economy took place with greater reliance on agricultural production, there are no data at present to support this. Subsistence resources on Vorovoro and Kavewa islands do not appear to have appreciably changed since first landfall, the infilling/emergence of the Kavewa embayment notwithstanding. The presence of continuous occupation at these sites is also telling as it relates to the test of Geraghty's (1983) interpretations of Proto-Tokalau Fijian in eastern Vanua Levu. If correct in our interpretation of Kavewa and Vorovoro as founder colonies, and assuming the Vorovoro radiocarbon dates are robust, then first settlement of these islands and north-eastern Vanua Levu predates Tonga by almost 150 years (Burley et al. 2012). Cultural continuity of site occupation further rules out a later incursion from the south-east, at least as it might have been represented at these sites.

The Vorovoro-Kavewa relationship to western Polynesia is not totally disconnected. Dickinson's $(2011,2015)$ petrographic study of Vorovoro ceramic tempers has identified a tan paste Lapita sherd that incorporates the highly distinctive Nendo-Nukuleka temper type. To quote Dickinson (2011:3), this is dominated by quartz and pyroxene sand grains that are unusual for a volcanic sand temper, as quartz is normally derived only from felsic volcanic rocks whereas pyroxene is typically derived from more mafic volcanic rocks'. When this is combined with trace amounts of hornblende and an absence of orthopyroxene it configures this temper type. Dickinson also notes that, as yet, there exists no evidence for quartz pyroxene sand on Vanua Levu. The NendoNukuleka temper type has been found only in the founder site for Tonga at Nukuleka (multiple sherds) and in a single occurrence in Lapita ceramics from Nendo in the Reefs-Santa Cruz Islands of the eastern Solomon Islands (Burley and Dickinson 2010). It is exotic to both of those contexts as is presumably the case for Vorovoro. Wherever the Lapita settlers of Vorovoro and Kavewa may have come from, it is possible they share an origin and ancestral relationship with the first peoples into Polynesia.

Archaeological survey of Vanua Levu has only just begun and it is impossible to have even preliminary discussion of the Kavewa and Vorovoro sites within the larger context in which they occur. There exist only a few other finds of dentate-stamped ceramics including a single sherd from Ligaulevu Village on Mali Island (Burley survey notes) and a single sherd from Vaturekuka on the Qawa River (Parke 2000). In addition, Jones (2014) has excavated at Nukubalavu at the head of Natewa Bay and recovered a small assemblage of dentate-stamped ceramics and other Lapita associated materials. Survey and test excavations on Cikobia-I-Ra Island, $40 \mathrm{~km}$ north of the north-eastern tip (Udu Point) of Vanua Levu by Sand et al. (1999) similarly recovered a small assemblage of decorated Lapita wares. As can be determined from the data as reported, ceramics from all of these sites are similar to Late Eastern Lapita ceramic styles of Lau and Tonga in contrast to Kavewa and Vorovoro. The data, however, are simply insufficient to appraise the chronology for and nature of initial settlement on the Vanua Levu landscape. In fact, the only 
concrete statement that might be made is that some type of settlement expansion was underway by at least the Late Lapita era (c. 2700-2550 cal. BP). Separate colonisation events also cannot be ruled out for the northern versus southern Vanua Levu coasts.

Finally, we emphasise that the northern Vanua Levu landscape today is dominated by mangrove thicket along the coast. A mangrove distribution map for contemporary Fiji (Ellison and Fiu 2010:10) illustrates this coastline as amongst the densest stands in Fiji, with over 24700 ha of growth. Mangrove density impacts contemporary settlement distribution, coastal access, reef productivity and a range of other factors, not the least being archaeological survey logistics and visibility. There has yet to be a study of Vanua Levu mangrove development in the sense of its emergence and density over time. Nunn and Peltier (2001:209) reconstruct Lapita-age sea levels as c. $1 \mathrm{~m}$ higher than present, falling to current levels after $2000 \mathrm{cal}$. BP. What this higher sea level might mean for Vanua Levu mangrove growth is unclear. For Viti Levu, Nunn $(2007,2009)$ suggests it facilitated an altered ecology than present today, one where sedimentation on reef flats to support mangrove expansion was substantially more limited and where larger estuarine accumulations occurred only after sea levels began to fall. Hope et al. (2009:79) also suggest a Lapita-age geography with more open beaches, and where mangroves were less extensive and further inland in estuarine locales. Yet the possibilities for shorelines fringed with mangrove swamp cannot be totally discounted. This type of coast, and its limitations for coastal habitation, could be reflected in the limited numbers of Lapita and Late Lapita archaeological sites reported on Vanua Levu, survey limitations notwithstanding. We conclude, then, with the observation that future archaeological studies on Vanua Levu require a firmer understanding of coastal ecology and environments if we are going to gain more than limited insight into the colonisation and settlement of Fiji's second largest island.

\section{Acknowledgements}

We want to first thank the turaga ni koro and people of Kavewa Village who kindly welcomed us into their midst for the five-day project, despite severe drought conditions. The late William R. Dickinson carried out petrographic analysis of ceramics and provided field insights for both Vorovoro and Kavewa sites with considerable expertise. That expertise and his friendship will be sadly missed. Shea Henry sorted the faunal remains into appropriate categories while Vienna ChiChi Lam prepared the illustrations. To each and all we are indebted and appreciative.

\section{References}

Burley, D.V. 2010. Archaeological surveys of Kadavu, Vanua Levu and Viti Levu-2009 project report. Unpublished report, on file, Fiji Museum, Suva.

Burley, D.V. 2012. Exploration as a strategic process in the Lapita settlement of Fiji: The implications of Vorovoro Island. Journal of Pacific Archaeology 3(1):22-34.

Burley, D.V. and W.R. Dickinson 2010. Among Polynesia's first pots. Journal of Archaeological Science 37:1020-1026. doi.org/10.1016/j.jas.2009.12.002.

Burley, D.V. and K. LeBlanc 2015. Obfuscating migration and exchange: The misconceptions of an Eastern Lapita Province. In C. Sand, S. Chiu and N. Hogg (eds), The Lapita Cultural Complex in time and space: Expansion routes, chronologies and typologies, pp. 173-184. Archeologia Pasifika 4. Institut d'archéologie de la Nouvelle-Calédonie et du Pacifique (IANCP), Nouméa.

Burley D.V., M.I. Weisler and J.-x. Zhao 2012. High precision U/Th dating of first Polynesian settlement. PLoS ONE 7(11):e48769. doi.org/10.1371/journal.pone.0048769. 
Dickinson, W.R. 2011. Petrography of Lithic manuports and the sand tempers of prehistoric potsherds from Vorovoro Islet off Vanua Levu in northern Fiji. Petrographic Report WRD-297. Unpublished report on file with author, Simon Fraser University, Burnaby.

Dickinson, W.R. 2015. Petrography of sand tempers in prehistoric potsherds from Kavewa Islet off Vanua Levu in northern Fiji. Petrographic Report WRD-319. Unpublished report on file with author, Simon Fraser University, Burnaby.

Ellison, J. and M. Fiu 2010. Vulnerability of Fijis mangroves and associated coral reefs to climate changeA review. World Wildlife Fund, South Pacific Office, Suva.

Geraghty, P.A. 1983. The history of the Fijian languages. Oceanic Linguistics Special Publication 19. University of Hawai'i Press, Honolulu.

Gifford, E.W. 1951. Archaeological excavations in Fiji. University of California Anthropological Records 13:189-288. University of California Press, Berkeley and Los Angeles.

Hope, G., J. Stevenson and W. Southern 2009. Vegetation histories from the Fijian Islands: Alternative records of human impact. In G. Clark and A. Anderson (eds), The early prehistory of Fiji, pp. 41-62. Terra Australis 31. ANU E Press, Canberra. doi.org/10.22459/ta31.12.2009.04.

Irwin, G., T.H. Worthy, S. Best, S. Hawkins, J. Carpenter and S. Matararaba 2011. Further investigations at the Naigani Lapita site (VL 21/5), Fiji: Excavation, radiocarbon dating and palaeofaunal extinction. Journal of Pacific Archaeology 2(2):66-78.

Jones, S. 2014. Archaeological survey and excavations at Nukubalavu, Vanua Levu, Fiji-2013 project. Unpublished report, on file, Fiji Museum, Suva.

LeBlanc, K. 2016. A structural approach to ceramic design analysis: A pilot study of the 'Eastern Lapita Province'. Journal of Archaeological Science: Reports 6:125-135. doi.org/10.1016/j.jasrep.2016.01.032.

Nunn, P.D. 2007. Echoes from a distance: Research into the Lapita occupation of the Rove Peninsula, southwest Viti Levu, Fiji. In S. Bedford, C. Sand and S.P. Connaughton (eds), Oceanic explorations: Lapita and Western Pacific settlement, pp. 163-176. Terra Australis 26. ANU E Press, Canberra. doi.org/10.22459/TA26.2007.

Nunn, P.D. 2009. Geographical influences on settlement-location choices by initial colonizers: A case study of the Fiji Islands. Geographical Research 47:306-319. doi.org/10.1111/j.1745-5871.2009.00594.x.

Nunn, P.D. and M.T. Carson 2015. Sea-level fall implicated in profound societal change about $2570 \mathrm{cal}$. BP (620 BC) in Western Pacific island groups. Geography and Environment 2:17-32. doi.org/10.1002/geo2.3.

Nunn P.D. and T.A. Heorake 2009. Understanding the place properly: Palaeogeography of selected Lapita sites in the western tropical Pacific Islands and its implications. In P.J. Sheppard, T. Thomas and G.R. Summerhayes (eds), Lapita: Ancestors and descendants, pp. 235-254. New Zealand Archaeological Association Monograph 28. New Zealand Archaeological Association, Auckland.

Nunn, P.D. and W.R. Peltier 2001. Far-field test of the ICE-4G model of global isostatic response to deglaciation using empirical and theoretical Holocene sea-level reconstructions for the Fiji Islands, Southwestern Pacific. Quaternary Research 55:203-214. doi.org/10.1006/qres.2000.2205.

Parke, A. 1971. Some prehistoric Fijian ceremonial sites on the island of Vanua Levu, Fiji. Archaeology and Physical Anthropology in Oceania 6(3):243-267.

Parke, A. 1972. Some prehistoric Fijian ceremonial sites on the island of Vanua Levu, Fiji (continued). Archaeology and Physical Anthropology in Oceania 7(1):56-78. 
Parke, A. 2000. Coastal and inland Lapita sites in Vanua Levu, Fiji. Archaeology in Oceania 35:116-119. doi.org/10.1002/j.1834-4453.2000.tb00464.x.

Rickard, M.J., 1966. Reconnaissance geology of Vanua Levu. Geological Survey of Fiji Memoir 2, Suva.

Ross-Sheppard, C., C. Sand, J. Balenaivalu and D.V. Burley 2013. Kutau/Bao obsidian-extending its eastern distribution in the Fijian northeast. Journal of Pacific Archaeology 4(2):79-83.

Sand, C., F. Valentin, T. Sorovi-Vunidilo, J. Bole, A. Ouetcho, S. Matararaba, J. Naucabalavu, D. Baret and L. Lagarde 1999. Cikobia-I-Ra, archaeology of a Fijian island. Les Cahiers de l'archéologie en Nouvelle-Calédonie 9. Département Archéologie, Service des Musées et du Patrimoine de NouvelleCalédonie, Nouméa. 
This text is taken from Debating Lapita: Distribution, Chronology, Society and Subsistence, edited by Stuart Bedford and Matthew Spriggs, published 2019 by ANU Press,

The Australian National University, Canberra, Australia.

doi.org/10.22459/TA52.2019.08 